\title{
UJI AKTIVITAS FAGOSITOSIS MAKROFAG EKSTRAK ETANOL DAUN SUJI (Dracaena angustifolia (Medik.)Roxb. ) SECARA IN VITRO
}

\author{
Nestri Handayani ${ }^{1,2 *}$, Subagus Wahyuono ${ }^{2)}$, Triana Hertiani ${ }^{2)}$, Retno Murwanti ${ }^{2)}$ \\ ${ }^{1)}$ Program Studi Farmasi, FMIPA, Universitas Sebelas Maret Surakarta \\ ${ }^{2)}$ Fakultas Farmasi Universitas Gadjah Mada Yogyakarta \\ *Email : nestri.uns@gmail.com
}

\begin{abstract}
Immunomodulatory activity has been carried out on ethanol extract of suji leaf (Dracaena angustifolia (Medik.) Roxb with in vitro macrofag phagocytosis method. . Suji is a plant that is often used as a food coloring and has long been used medicinally. This study aimed to test in vitro macrophage phagocytosis on ethanol extract of suji leaf. The suji leaves are extracted by maceration method. The obtained viscous extract was then tested for Thin Layer Chromatography (TLC) and in vitro macrophage phagocytosis test. The parameters used are Phagocytosis Index and Macrophage Capacity. The results of in vitro macrophage phagocytosis test with 4 concentrations of 10.25,50 and 100 microgram / ml, showed for the largest average Fagocytosis (IF) Index shown at concentration $10 \mathrm{mcg} / \mathrm{ml}$, while concentrations 25 and $50 \mathrm{mcg} / \mathrm{ml}$ showed values The same phagocytic (KF) capacity.
\end{abstract}

Keywords : Suji leaf, Phagocytic Macrophage Activity, ethanolic extract

\begin{abstract}
ABSTRAK
Uji aktivitas imunomodulator telah dilakukan terhadap ekstrak etanol daun suji (Dracaena angustifolia (Medik.)Roxb.. Suji merupakan tanaman yang sering digunakan sebagai pewarna makanan dan telah lama digunakan untuk obat. Penelitian ini bertujuan untuk melakukan uji fagositosis makrofag in vitro terhadap ekstrak etanol daun suji. Daun suji diekstraksi dengan metode maserasi. Ekstrak kental yang diperoleh kemudian dilakukan uji Kromatografi Lapis Tipis (KLT) dan uji fagositosis makrofag in vitro. Parameter yang digunakan adalah Indeks fagositosis dan Kapasitas makrofag. Hasil uji fagositosis makrofag in vitro dengan 4 konsentrasi sebesar 10,25,50 dan 100 mikrogram/ml, menunjukkan untuk Indeks Fagositosis (IF) rata-rata terbesar ditunjukkan pada konsentrasi $10 \mathrm{mcg} / \mathrm{ml}$, sedangkan konsentrasi 25 dan $50 \mathrm{mcg} / \mathrm{ml}$ menunjukkan nilai Kapasitas Fagositosis (KF) yang sama besar.
\end{abstract}

Kata kunci : Daun suji, fagositosis makrofag, ekstrak etanol

Nestri Handayani dkk... 


\section{PENDAHULUAN}

Tanaman suji (Dracaena angustifolia

Roxb.) merupakan tanaman yang telah dikenal di Indonesia. Pemanfaatan utama tanaman suji oleh masyarakat adalah daunnya digunakan sebagai pewarna makanan dan sebagai tanaman obat (Heyne,1987). Suji dilaporkan mengandung beberapa golongan senyawa seperti saponin steroid flavonoid dan senyawa fenolat (Tran et al, 2001; Huang et al., 2013).

Imunomodulator adalah substansi biologi maupun sintetis yang dapat menstimulasi, menekan atau memodulasi komponen-komponen sistem imun, baik innate maupun adaptive (Agarwal dan Singh, 1999). Penyembuhan infeksi akan lebih cepat bila fungsi sistem imun tubuh ditingkatkan. Berbagai bahan asal tanaman dapat memacu fungsi berbagai komponen sistem imun nonspesifik (makrofag, sel NK) dan sistem imun spesifik (proliferasi sel $\mathrm{T}$, sel B yang memproduksi antibodi) serta produksi sitokin sehingga dapat digunakan dalam klinik sebagai adjuvan untuk penyembuhan berbagai penyakit infeksi (Baratawidjaja dan Rengganis, 2010).

Fagositosis merupakan proses ditelannya partikel oleh sel. Makrofag dan leukosit polimorfonuklear merupakan sel fagosit terpenting. Mayoritas benda asing yang masuk ke dalam jaringan dihilangkan melalui mekanisme fagositosis (Playfair dan Chain, 2009). Fagositosis makrofag banyak digunakan sebagai parameter imunologi untuk mengevaluasi kesehatan/fungsi kekebalan tubuh. Penilaian kemampuan/aktivitas fagositosis dapat dihitung dengan mengukur kapasitas fagositosis dan indeks fagositosis dan metode fagositosis adalah salah satu metode yang paling banyak digunakan untuk skrining bahan aktif yang mempengaruhi respon imun (Jensch-Junior et al., 2006)

\section{METODE PENELITIAN}

Alat - alat yang digunakan: Bejana maserasi, Rotavapor , alat-alat KLT, Spuit injeksi, mikropipet ,seperangkat alat alat gelas, alat bedah, mikroskop, haemositometer, incubator.

Bahan yang digunakan

Bahan yang digunakan yaitu daun D. angustifolia (diperoleh dari Merapi Farma yogyakarta), etanol 96\%, n- heksana, kloroform, methanol, air. Plat KLT Silika gel GF 254., Cerium sulfat.

Hewan coba mencit putih galur Swis Wistar (jantan) usia 2-3 bulan, FBS (Fetal Bovine Serum), media RPMI (Rosewell Park Memorial Institute) 1640 (Sigma), Natrium bikarbonat, PBS (Phosphate Buffered Saline), sumuran microplate dan coverslip, suspensi lateks (Sigma), kloroform dan Giemsa untuk pewarnaan.

\section{Prosedur kerja}

1. Pembuatan ekstrak dan fraksi

a. Ekstraksi

Serbuk daun suji kering dimaserasi dengan etanol $96 \%$ pada suhu kamar selama 1 x 24 jam. Hasil maserasi selanjutnya dilakukan penyaringan untuk memisahkan filtrat dari residunya. Residu dilakukan remaserasi agar penyarian lebih efektif. Filtrat hasil maserasi dan remaserasi dicampur hingga homogen kemudian dievaporasi hingga dihasilkan ekstrak kental. 
2. Uji fagositosis makrofag in vitro

a. Preparasi ekstrak dan fraksi uji

Ekstrak/fraksi dilarutkan dalam DMSO $0,5 \%$ v/v dalam air suling steril. Dibuat seri konsentrasi 10, 20, 50 dan $100 \mu \mathrm{g} / \mathrm{ml}$. Masing-masing ekstrak uji disiapkan sebanyak $1 \mathrm{ml}$ untuk pengujian imunomodulator.

b.Isolasi sel makrofag

Makrofag diisolasi dari mencit jantan umur 8 -12 minggu. Mencit dikorbankan dengan eter, kemudian dibedah hingga tampak rongga perutnya. Masukkan media kurang lebih $10 \mathrm{ml}$ RPMI dingin ke dalam rongga perut dan pijat secara lembut selama kurang lebih 5 menit, selanjutnya cairan RPMI dalam rongga perut diambil lagi dan dilakukan sentrifuge 1200 selama10 menit, selanjutnya jumlah sel dihitung dengan haemositometer dan disuspensikan hingga konsentrasi $2.5 \quad$ x $\quad 10^{5} \quad$ sel/sumuran. Selanjutnya sel makrofag diinkubasikan selama 24 jam. (Spilsbury et al ,1999)

c.Pengukuran aktivitas makrofag mencit in vitro

Setelah sel makrofag dikultur selama 24 jam, media diambil dengan pipet dan dicuci dengan sebanyak dua kali. Bahan uji ditambahkan sebanyak $1 \mathrm{ml}$ sedangkan pada kelompok kontrol pelarut MK dan DMSO masing-masing $1 \mathrm{ml}$ untuk tiap konsentrasi dengan pengulangan sebanyak 2 kali. Inkubasi selama 4 jam di dalam inkubator $\mathrm{CO}_{2}$ dengan suhu $37^{\circ}$ C. Lateks beads berdiameter 3 um disuspensikan dalam PBS hingga konsentrasinya $2,5 \times 10^{7}$ lateks $/ \mathrm{ml}$. Suspensi lateks sebanyak 200ul ditambahkan dalam sumuran dan diinkubasi selama 20 menit untuk memberi kemampuan makrofag berinteraksi dengan lateks pada suhu $37^{\circ} \mathrm{C}$ pada inkubator $\mathrm{CO} 25 \%$. Cover slip dicuci dengan PBS sebanyak $3 x$ untuk menghilangkan partikel yang tak terfagositosis dan dikeringkan pada suhu ruang. Fiksasi coverslip dengan metanol absolut selama 30 detik untuk membuka membran makrofag dan dikeringkan pada suhu ruang, setelah itu ditetesi cat giemsa hingga coverslip terendam selama 30 menit, cuci dengan aquades, keringkan dan amati dengan mikroskop.

Fagositosis makrofag banyak digunakan sebagai parameter imunologi untuk mengevaluasi kesehatan/fungsi kekebalan tubuh. Penilaian kemampuan/aktivitas fagositosis dapat dihitung dengan mengukur kapasitas fagositosis (KF) dan indeks fagositosis (IF)

Indeks fagositosis (IF) $: \frac{\text { Jumlah lateks yang terfagositosis }}{\text { Jumlah makrofag yang aktif (100) }}$

Kapasitas fagositosis (KF) : Jumlah makrofag yang memfagositosis $\times 100 \%$

Jumlah makrofag yang dihitung (100)

(Jensch-Junior et al., 2006).

Nestri Handayani dkk... 


\section{HASIL DAN PEMBAHASAN}

Ekstraksi daun suji dilakukan dengan metode maserasi,yaitu dengan merendam serbuk daun suji kering dalam pelarut etanol $96 \%$. Meskipun metode maserasi bukan merupakan metode yang paling efektif namun cukup mudah dilaksanakan dan cukup efektif untuk menyari zat aktif dari tanaman. Dari hasil maserasi yang diuapkan pada rotavapor sehingga menjadi ekstrak kental, didapatkan rendemen 9,23\%.

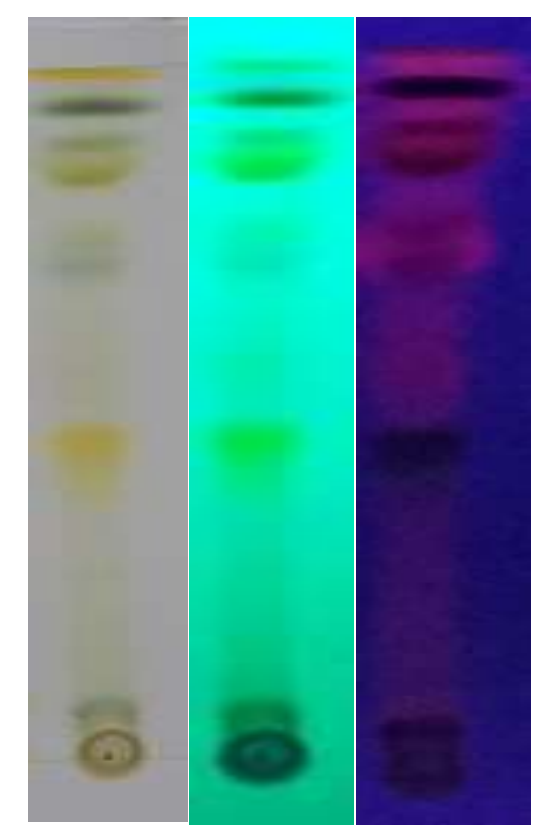

A

B

C

\section{Gambar 1. Profil KLT ekstrak daun suji}

Keterangan : fase diam : Silika gel F254; fase gerak : heksana-etil asetat $=4: 1$
A. Hasil KLT diamati dengan sinar tampak
B. Hasil KLT diamati dengan sinar uv254
C. Hasil KLT diamati dengan sinar uv366

\section{Hasil uji aktivitas imunomodulator}

Uji fagositosis makrofag dilakukan dengan 4 tingkat konsentrasi 10,25,50 dan $100 \mu \mathrm{g} / \mathrm{ml}$ dan ditambah kontrol pelarut dan kontrol media untuk memastikan bahwa pelarut dan media yang digunakan tidak berpengaruh terhadap proses fagositosis makrofag. fraksi-fraksi memiliki aktivitas imunomodulator.

Makrofag merupakan sel fagositik utama yang berperan menangkal serangan patogen melalui mekanisme fagositosis, berperan penting baik pada respon imun bawaan maupun respon imun adaptif. Kemampuan fagositosis makrofag dapat 
diukur dari kemampuannya dalam memfagositosis partikel lateks. Penggunaan lateks beads berdasarkan ukurannya yang mirip dengan bakteri, dan dipilih lateks berukuran $3 \mu \mathrm{m}$, sesuai dengan rentang ukuran bakteri yaitu 1-10 $\mu \mathrm{m}$ dan disesuaikan juga dengan besar ukuran makrofag yaitu 100-225 $\mu \mathrm{m}$ (Abbas et al., 2007; Baratawidjaja dan Rengganis, 2012).

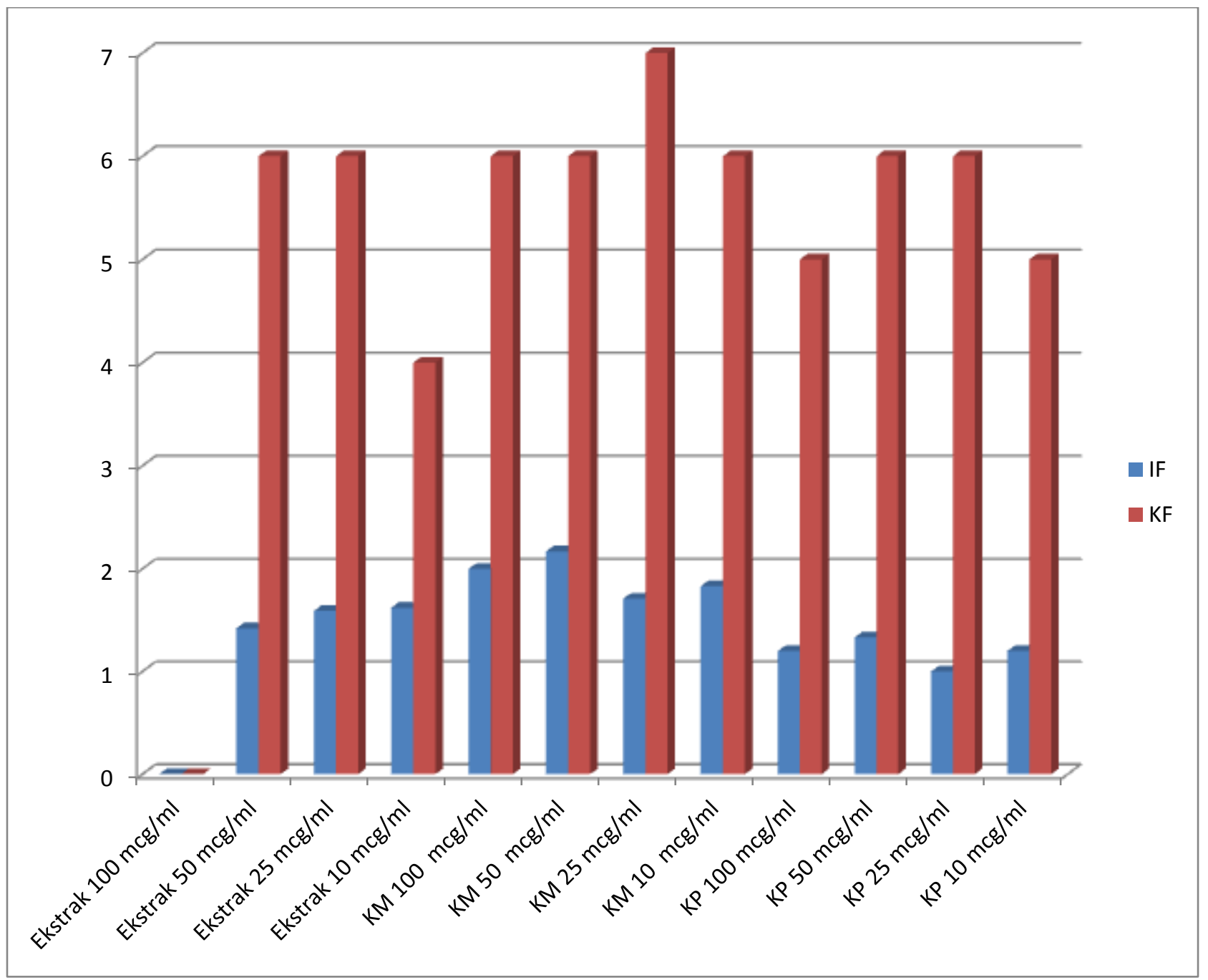

Gambar 2. Grafik indeks fagositosis dan kapasitas fagositosis berbagai konsentrasi ekstrak

Keterangan :

KM : Kontrol media ; KP : Kontrol pelarut

Nestri Handayani dkk... 
Uji aktivitas fagositosis makrofag menggunakan parameter indeks fagositosis yaitu jumlah partikel lateks yang dapat difagositosis oleh 100 makrofag aktif dan

Lateks yang dimakan menandakan bahwa proses fagositosis terjadi. Dari gambar 2 terlihat bahwa dari empat tingkat konsentrasi, pada konsentrasi 100 microgram $/ \mathrm{ml}$ tidak tampak adanya makrofag yang bisa diamati, kemungkinan pada konsentrasi tersebut tidak Sedangkan pada konsentrasi $50 \mathrm{mcg} / \mathrm{ml}$ diperoleh nilai IF terendah sebesar 1.42. Senyawa yang memiliki nilai $I F>1$, digolongkan sebagai senyawa imunostimulan, berarti zat yang dapat menstimulir atau meningkatkan daya tahan tubuh, sedangkan senyawa dengan nilai IF $<1$ digolongkan sebagai senyawa imunosupresan yang berarti zat yang dapat menekan daya tahan tubuh (Kresno, 2007). Dilihat dari nilai IF pada Gambar 2, dapat disimpulkan kalau ekstrak etanol daun suji pada konsentrasi 10, 25 dan $50 \mathrm{mcg} / \mathrm{ml}$ merupakan imunostimulan dan konsentrasi $10 \mathrm{mcg} / \mathrm{ml}$ dapat dikatakan memiliki daya imunostimulator terbesar. Untuk kapasitas fagositosis terlihat bahwa konsentrasi 10 $\mathrm{mcg} / \mathrm{ml}$ menunjukkan nilai KF terkecil, dengan nilai $4 \%$, sedang untuk konsentrasi kapasitas fagositosis yaitu jumlah makrofag yang mampu memakan partikel lateks. Partikel lateks yg dimakan oleh makrofag berbentuk bulatan kuning yang berpendar. memungkinkan kultur makrofag untuk tumbuh.

25 dan $50 \mathrm{mcg} / \mathrm{ml}$ menunjukkan nilai $\mathrm{KF}$ sama, sebesar $6 \%$.

Sedang pada uji Indeks Fagositosis terlihat bahwa nilai IF tertinggi dicapai pada konsentrasi ekstrak terkecil yaitu 10 mikrogram/ml, yang mencapai nilai 1.62 .

\section{KESIMPULAN}

Dilihat dari nilai Indeks Fagositosis, konsentrasi ekstrak sebesar $10 \mathrm{mcg} / \mathrm{ml}$ dapat dikatakan memiliki aktivitas fagositosis makrofag terbesar, namun jika dilihat dari nilai Kapasitas Fagositosis, aktivitas yang terbesar diperoleh pada konsentrasi 25 dan $50 \mathrm{mcg} / \mathrm{ml}$ yang memiliki nilai KF sama.

\section{DAFTAR PUSTAKA}

Abbas, A. K., Lichtman, A.H., 2015., Cellular and Molecular Immunology, $8^{\text {th }}$ edition, Elsevier. Oxford.

Agarwal., S.S., Singh,V.K., 1999 , Immunomodulators : Areview of Studies on Indian Medicinal Plants and Synthetic Peptides, 179 
Bratawidjaja , KG, Rengganis, I., 2010, Imunologi Dasar, 9th ed, Fakultas Kedokteran Universitas Indonesia, Jakarta, p.47

Heyne, K.,1950, Tumbuhan Berguna Indonesia, Jilid I, Terjemahan Badan Litbang Kehutanan, cetakan ke-1, Departemen Kehutanan, Jakarta.

Huang, H.C., Lin., M.K., Hwang., S.Y., Hwang., L.T., Kuo.,Y.H., Chang., C.I., 2013, Two Anti-inflamatory Steroidal Saponins from D.angustifolia, Molecules, 18, 8752-8763

Kresno, S.B. 2007. Imunologi: Diagnosis dan Prosedur Laboratorium.Edisi IV, Cetakan ke 83. Jakarta: Penerbit Universitas Indonesia

Jensch-Junior,B.E., Pressinotil.,N., Borges, J.C.S and Silva, C.D., 2006,
Characterization of Macrophage Phagocytosis of the Tropical Fish Prochilodus srofa, Aquaculture, 251 : 509-515

Playfair, J.H.L., Chain, B.M., 2009, At a Glance Imunologi, edisi 9, diterjemahkan Winardini, Penerbit Erlangga, Jakarta.

Spillsbury, K., Omara, M.A, Wu, W.M., Rowe,P.B dan Takayama, Y., 1995, Isolation of a Novel MacrophageSpecific Gene by Differential cDNA Analysis, Blood,85,1620-1629

Tran, Q.L.; Tezuka, Y.; Banskota, A.H.; Tran, Q.K.; Saiki, I.; Kadota, S,2001, New spirostanol steroids and steroidal saponins from roots and rhizomes of D.angustifolia and their antiproliferative activity, J. Nat. Prod. 64, 1127-1132.

Nestri Handayani dkk... 